\title{
PENGARUH INTERNATIONAL STANDART OF ORGANIZATION, KUALITAS AUDITOR INTERNAL, DAN KONTRAK MANAJEMEN TERHADAP KUALITAS LABA
}

\author{
Riski Ulan Sari \\ Universitas Muhammadiyah Tangerang \\ riskiulan4@gmail.com
}

\section{ABSTRACT}

The purpose of this study was to determine the effect of ISO, quality of internal auditors, and management contracts on earnings quality in manufacturing companies listed on the Indonesia Stock Exchange. The time period of the study is 4 years, namely the period 20152018. The population of this study includes all manufacturing companies listed on the Indonesia Stock Exchange in the 2015-2018 period. The sampling technique uses purposive sampling technique. Based on predetermined criteria obtained 9 companies. The type of data used is secondary data obtained from the Indonesia Stock Exchange website. The analytical method used is panel data regression analysis using the eviews 9.0 data processing program The results showed that ISO has a significant positive effect on earnings quality, while the quality of internal auditors and contract management negatively affects earnings quality.

Keywords: Profit Quality, ISO, Quality of Internal Auditors, and Management Contract

\section{PENDAHULUAN}

Laba merupakan salah satu ukuran untuk menilai keberhasilan perusahaan. Laba akuntansi merupakan selisih antara pendapatan dan pengeluaran dari hasil operasional perusahaan (Basuki, 2016). Laba digunakan oleh pihak eksternal sebagai indikator untuk mengukur kinerja operasional perusahaan (Warianto, 2014). Kualitas laba merupakan tingkat perbedaan antara laba bersih yang dilaporkan dengan laba yang sesungguhnya, sehingga laba yang berkualitas mencerminkan kinerja keuangan perusahaan yang sebenarnya tanpa adanya manipulasi. Laba tercatat yang tidak sesuai dengan kondisi laba yang sesungguhnya tidak dapat memproyeksikan kinerja keuangan yang sebenarnya sehingga menjadi tidak relevan dan reliabel untuk digunakan sebagai dasar pengambilan keputusan (pertiwi, 2017). Dampak dari laporan kualitas laba yang baik juga akan mempengaruhi kegiatan perusahaan dalam penyerapan saham menjadi optimal, sehingga tingkat pengambilan atas saham tersebut menjadi lebih baik. Hal ini menyebabkan perusahaan bisa bersaing dalam era globalisa dikarenakan banyak calon investor yang berminat untuk berinvestasi diperusahaan tersebut.

Sistem manajemen mutu (SMM) merupakan sekumpulan prosedur terdokumentasi dan praktek-praktek standar untuk manajemen sistem yang bertujuan menjamin kesesuaian dari suatu proses dan produk terhadap kebutuhan atau persyaratan tertentu. Kebutuhan atau persyaratan itu ditentukan atau dispesifikasikan oleh pelanggan dan organisasi. SMM mendefinisikan bagaimana organisasi menerapkan praktek-praktek manajemen mutu secara konsisten untuk memenuhi 
kebutuhan pelanggan dan pasar (Semuel \& Zulkarnain, 2014). Hal ini dikarenakan konsumen sangat meningkatkan tuntutan mereka akan kualitas, dan kecenderungan ini kiranya akan diperkuat oleh tekanan persaingan di masa mendatang. Teknologi baru telah memungkinkan produk memberikan fungsi lebih baik dan tingkat penampilan yang lebih tinggi. Sebagai akibat dari tuntutan konsumen yang meningkat akan kualitas, dan pengembangan teknologi produk baru, banyak teknik dan praktik jaminan kualitas yang ada perlu diubah seperlunya (Hadi Firmansyah, 2015).

Pengelolaan usaha yang terfokus pada fleksibilitas dan kualitas dengan wawasan global dapat tercermin dari sistem manajemen mutu (SMM) yang dijalankan oleh organisasi bisnis. Salah satu standar sistem manajemen mutu yang telah berkembang di negara maju dan negara berkembang adalah sistem manajemen mutu (SMM) ISO 9001. Standar ini merupakan sarana atau alat untuk mencapai tujuan mutu yang diharapkan mampu menjawab tantangan globalisasi dimana tujuan akhirnya adalah mencapai efektivitas dan efisiensi organisasi. Perolehan sertifikasi SMM ISO 9001 pada sebuah organisasi mengartikan bahwa organisasi tersebut telah menjalankan sistem manajemen mutu yang diakui secara internasional (Antariksa \& Setiawan, 2014).

Rosnidah (2013), menyatakan bahwa kualitas audit dari auditor internal masih menjadi sorotan karena auditor internal berada dalam organisasi dan digaji oleh organisasi sehingga independensi auditor internal terkadang masih diragukan. Sebagai pihak internal perusahaan, maka beberapa aktivitas dalam proses audit yang dilakukan mungkin akan lebih berpihak pada keuntungan yang diperoleh perusahaan yang memungkinkan untuk menutupi segala aktivitas perusahaan yang kurang baik.
Kualitas audit internal dalam perusahaan sebagai suatu indikator pengendalian terhadap segala kecurangan-kecurangan dan kesalahan-kesalahan yang rentan dilakukan oleh manajemen perusahaan. Jika kualitas audit internal kurang baik, maka hal tersebut mengindikasikan bahwa fungsi pengendalian internal dalam perusahaan tersebut juga rendah.

Oleh karena itu, semakin berkualitas auditor yang mengaudit laporan keuangan suatu perusahaan, maka investor beranggapan bahwa kualitas dari laporan keuangan tersebut juga semakin baik. Auditor memberikan opini terhadap laporan keuangan khususnya informasi laba sehingga informasi laba yang dilaporkan perusahaan menjadi lebih kredibel yang akan berdampak pada tingginya kualitas laba perusahaan.

Menurut Jawat (2014), kontrak manajemen adalah kegiatan untuk mengelola suatu kontrak agar kontrak tersebut dapat digunakan sebagai alat pengendalian pelaksanaan pekerjaan. Mchopa (2015), menyatakan bahwa praktik kontrak manajemen yang sukses dan efisien adalah mereka yang memenuhi kebutuhan para pemangku kepentingan perusahaan.

Oleh karena itu, dengan melakukan kontrak manajemen yang baik maka akan membentuk image perusahaan yang baik dan mempengaruhi stakeholders dalam merespon positif informasi laba yang dipublikasikan sehingga akan berdampak pada tingginya kualitas laba perusahaan.

\section{TINJAUAN PUSTAKA DAN HIPOTESIS}

Stewardship Theory

Menurut Donaldson dan Davis (1991), teori stewardship adalah teori yang menggambarkan situasi dimana para manajer tidaklah termotivasi oleh tujuan- 
tujuan individu tetapi lebih ditujukan pada sasaran hasil utama mereka untuk kepentingan organisasi. Teori ini mempunyai dasar psikologi dan sosiologi yang telah dirancang dimana para eksekutif sebagai steward termotivasi untuk bertindak sesuai keinginan prinsipal. Selain itu perilaku steward tidak akan meninggalkan organisasinya sebab mereka berusaha mencapai sasaran organisasinya. perusahaan.

Hubungan stewardship theory dalam penelitian ini terletak pada kualitas auditor internal. Peran auditor disini merupakan fungsi yang independen yang ada dalam suatu organisasi dan memiliki tujuan untuk menguji serta mengevaluasi hasil dari kegiatan-kegiatan operasional perusahaan yang dilaksanakan oleh perusahaan itu sendiri seperti penyusunan laporan keungan. Hasil dari penyusunan laporan keungan yang dibuat oleh bagian keuangan akan diaudit terlebih dahulu oleh auditor internal sebelum dilaporkan dan dipublikasikan ke masing-masing stakeholder untuk mencegah terjadinya seorang manajer melakukan manipulasi data dalam laporan keuangan perusahaan. Dengan demikian tujuan perusahaan dalam mendaptkan laba perusahaan yang berkualitas akan tercapai.

\section{Teori Akuntansi Positif}

Menurut Watts \& Zimmerman (1978), dorongan terbesar dari teori akuntansi positif dalam akuntansi adalah untuk menjelaskan (to explain) dan meramalkan (to predict) pilihan stnadar manajemen melalui analisis atas biaya dan manfaat dari pengungkapan keuangan tertentu dalam hubungannya dengan berbagai individu dan pengalokasian sumber daya ekonomi. Teori akuntansi positif didasarkan pada adanya dalil bahwa manajer, pemegang saham, dan aparat pengatur adalah rasional dan bahwa mereka berusaha untuk memaksimalkan kegunaan mereka yang secara langsung berhubungan dengan kompensasi mereka, dan tentunya kesejahteraan mereka pula. Pilihan atas suatu kebijakan akuntansi oleh beberapa kelompok tersebut bergantung pada perbandingan relatif biaya dan manfaat dari prosedur akuntansi alternatif dengan cara demikian untuk memaksimalkan kegunaan mereka. Magdalena (2018) dalam penelitianya mengemukakan bahwa Positive Accounting Theory menekankan apakah teori akuntansi yang dikemukakan dalam literatur akuntansi dapat menjelaskan praktik-praktik akuntansi yang dilakukan dan meramalkan sebab dari fenomena yang sedang terjadi sekarang ini serta pengaruhnya di masa mendatang.

Hubungan teori akuntansi positif dalam penelitian ini terletak pada Kualitas Laba, sikap manajemen yang berupaya untuk mencapai tujuan perusahaan yaitu mendapatkan laba perusahaan yang maksimal dan baik. Untuk mencapai tujuan tersebut seorang manajer bekerjasama dengan para staffnya dalam memilih metode akuntansi untuk setiap kegiatan operasi perusahaan. Manajer berupaya memilih metode akuntansi yang lebih efisien dan efektif untuk menaikkan laba perusahaan tanpa melepaskan ke tiga hipotesis teori akuntansi positif sehingga dengan pemilihan metode akuntansi yang tepat akan berdampak terhadap laba yang dihasikan oleh perusahaan, manajer harus memilih kebijakan akuntansi yang sesuai dengan tujuan perusahaan sehingga laporan keuangan yang disajikan akan berkualitas. Laporan keuangan yang berkualitas akan membuat image perusahaan menjadi baik, sehingga mempengaruhi investor untuk merespon positif baik informasi laba yang 
dilaporkan perusahaan dan akan meningkatkan kualitas laba perusahaan.

\section{Teori Stakholders}

Stakeholder adalah kelompok atau individu yang dapat mempengaruhi dan atau dipengaruhi oleh suatu pencapaian tujuan tertentu (Freeman, 1984). Teori stakeholders menyatakan bahwa perusahaan bukanlah entitas yang hanya beroperasi untuk kepentingannya sendiri namun harus memberikan manfaat bagi para stakeholders perusahaan sehingga tujuan perusahaan akan tercapai (Natasya, 2016). Kelompok utama stakeholder terdiri atas pelanggan, pekerja, komunitas lokal, pemasok dan distibutor, dan pemegang saham. Selain itu, kelompok dan individu lain yang termasuk stakeholder adalah media, masyarakat umum, partner bisnis, generasi akan datang, generasi masa lalu (pendiri suatu organisasi), akademis, kompetitor, organisasi swasta atau para aktivis, wakil stakeholder yang dapat berupa serikat atau asosiasi perdagangan, pemegang saham (kreditur dan bondholders), pemerintah, regulator dan pembuat kebijakan (Suwandi \& Daromes, 2017). Dengan kata lain perusahaan dalam beroperasi membutuhkan bantuan dari pihak luar salah satunya adalah dukungan dari masyarakat.

Hubungan teori stakeholder dengan penelitian ini juga terletak pada kontrak manajemen. yaitu kontrak atau perjanjian yang dibuat oleh perusahaan dengan stakeholders perusahaan. kontrak manajemen adalah kegiatan untuk mengelola suatu kontrak agar kontrak tersebut dapat digunakan sebagai alat pengendalian pelaksanaan pekerjaan. Dengan adanya kontrak manajemen tujuan perusahaan akan mudah tercapai, karena dengan adanya kontrak kebutuhan dari masing-masing pembuat kontrak akan tercukupi. Kontrak yang sukses dan efisien adalah mereka yang memenuhi kebutuhan para pemangku kepentingan perusahaan. Oleh karena itu dengan melakukan kontrak manajemen yang baik maka akan membentuk image perusahaan yang baik dan mempengaruhi stakeholders dalam merespon positif informasi laba yang dipublikasikan sehingga akan berdampak pada tingginya kualitas laba perusahaan.

\section{Pengaruh ISO terhadap Kualitas Laba}

ISO adalah badan penetap standar internasional yang tediri dai wakil-wakil dari badan standar nasional setiap negara. ISO dibentuk untuk meningkatkan perdagangan internasional yang berkaitan dengan perubahan barang dan jasa. Walaupun pada awalnya lembaga ISO tidak khusus merancang standar yang dipakai pada perdagangan, namun dalam perjalanannya kebutuhan standar tidak terlepas dari persyaratan dunia perdagangan. Keberhasilan ISO pada tahun 1987 menjadikan ISO sebagai standar yang dinilai paling fair dalam perdagangan dunia (Semuel \& Zulkarnain, 2014).

Penerapan ISO akan meningkatkan kinerja perusahaan karena dengan adanya ISO kegiatan perusahaan menjadi terencana dan terstruktur. Hal ini sesuai dengan penelitian yang dilakukan oleh Antariksa \& Setiawan (2014) yang menjelaskan bahwa sertifikasi ISO ditemukan berhubungan dengan peningkatan kinerja keuangan yang diukur dengan peningkatan kinerja karyawan, peningkatan pendapatan penjualan, penurunan biaya pokok penjualan dan peningkatan rasio perputaran aset perusahaan bersertifikat. Penelitian dari Semuel \& Zulkarnain (2014) menjelaskan Penerapan ISO mampu meningkatkan kinerja karyawan secara signifikan melalui budaya kualitas 
perusahaan sebagai mediasinya yang menyebabkan laba perusahaan menjadi meningkat.

Belum banyak penelitian mengenai pengaruh ISO terhadap kualitas laba, namun jika dilihat dari penelitian yang dilakukan oleh Antariksa \& Setiawan (2014) serta Semuel \& Zulkarnain (2014) mengenai ISO, menunjukan bahwa penerapan ISO dapat meningkatkan laba perusahaan melalui peningkatan kinerja perusaahan. Peningkatan kinerja perusahaan itu sendiri bisa dilihat dari meningkatnya suatu kinerja karyawan dan kinerja keuangan. Perusahaan yang memiliki banyak sertifikat ISO akan membuat image perusahaan menjadi baik dimata masyarakat. Masyarakat akan pecaya bahwa produk yang dihasilkan berkualitas. Hal ini akan mempengaruhi stakeholders dalam penilaian terhadap laporan informasi laba yang dihasilkan dianggap berkualitas. Seiring dengan kepercayaan stakeholders terhadap informsi laba, maka kualitas laba yang dihasilkan akan baik. Berdasarkan uraian tersebut maka hipotesis yang akan diajukan adalah : $\mathrm{H}_{1}$ : ISO berpengaruh positif terhadap Kualitas Laba

\section{Pengaruh Kualitas Auditor Internal terhadap Kualitas Laba}

Audit internal adalah pemeriksaan yang dilakukan oleh bagian auditor internal perusahaan, baik terhadap laporan keuangan dan catatan akuntansi perusahaan, maupun ketaatan terhadap kebijakan manajemen puncak yang telah ditentukan dan ketaatan terhadap peraturan pemerintah dan ketentuan-ketentuan dari ikatan profesi yang berlaku (Rosnidah, 2017). Auditor internal akan melakukan pengkajian, pengevaluasian dan memberikan rekomendasi secara independen dan objektif terhadap aktivitas perusahaan/organisasi sehingga organisasi dapat mencapai tujuannya.

Dalam penelitian Rosnidah (2017) dan Ariany (2017) menjelaskan bahwa seorang auditor bisa dikatakan berkualitas jika memiliki independensi dan kompetensi yang baik ketika dalam mengaudit sebuah laporan keuangan. Dengan demikian, semakin tinggi independensi dan kompetensi seorang auditor maka akan menghasilkan kualitas audit yang lebih tinggi pula, begitu juga sebaliknya.

Belum banyak yang melakukan penelitia tentang kualitas auditor terhadap kualitas laba, namun jika dilihat dari penelitian yang dilakukan oleh Rosnidah (2017) dan Ariany (2017) mengenai kualitas auditor internal, menjelaskan bahwa seorang auditor internal yang berkualitas akan menghasilkan hasil audit yang berkualitas dengan memberikan sebuah opini terhadap laporan keungan khususnya informasi yang dilaporkan perusahaan menjadi lebih kredibel dan akan berpengaruh pada meningkatnya respon positif dari pasar terhadap infromasi laba dilaporkan. Hal ini akan menyebabkan kualitas laba perusahaan akan menjadi lebih baik. Berdasarkan uraian tersebut maka hipotesis yang akan diajukan adalah :

$\mathrm{H}_{2}$ : kualitas Auditor berpengaruh positif terhadap Kualitas Laba

\section{Pengaruh Kontrak Manajemen Terhadap Kualitas Laba}

Kontrak manajemen adalah kegiatan untuk mengelola suatu kontrak agar kontrak tersebut dapat digunakan sebagai pedoman dan sebagai alat pengendalian pelaksanaan pekerjaan. Karena itu perlu dilakukan pengelolaan penyusunan dan pengadministrasian kontrak (Jawat, 2014). 
Dalam kontrak kerja terdapat kelengkapan spesifikasi dan klausal-klausal tentang pekerjaan, sehingga kontrak kerja menjadi pedoman dari keseluruhan pelaksanaan proyek. Penerapan kontrak kerja diharapkan dapat mempermudah owner dan kontraktor menjalankan kewajibannya dalam pelaksanaan proyek. Kontrak kerja juga merupakan landasan hukum atas owner dan kontraktor, sehingga apabila salah satu pihak melakukan kelalaian, maka dapat menerima konsekuensi. (Tumembow, 2016)

Penelitian yang dilakukan Jawat (2014) menjelaskan kontrak manajemen digunakan sebagai pedoman dan sebagai alat pengendalian pelaksanaan pekerjaan agar kerjasama antar perusahaan tetap terjaga. Sedangkan menurut Tumembow (2016) menjelaskan bahwa kontrak kerja merupakan landasan hukum atas owner dan kontraktor, sehingga apabila salah satu pihak melakukan kelalaian dan pelanggaran, maka dapat menerima konsekuensi. Hal ini akan berdampak pada penilai masyarakat terhadap perusahaan akan buruk.

Belum banyak penelitian yang menjelaskan pengaruh Kontrak Manajemen terhadap kualitas laba. Akan tetapi jika dilihat dari penelitian yang dilakukan oleh Jawat (2014) dan Tumembow (2016) tentang kontrak kerja dapat disimpulkan Perusahaan harus melakukan kontrak manajemen dengan baik agar terhindar dari sanksi yang telah disepakati bersama. Dengan melakukan kontrak mnajemen yang baik image perusahaan dimasyarakat menjadi baik. Dengan demikian penilaian stakeholders terhadap laporan informasi laba menjadi baik. Hal ini akan menyebabkan laba perusahaan menjadi berkualitas. Berdasarkan uaraian tersebut maka hipotesis yang diajukan adalah sebagai berikut :

$\mathrm{H}_{3}$ : Kontrak Manajemen berpengaruh positif terhadap Kualitas Laba

\section{METODE PENELITIAN}

\section{Populasi dan Sampel}

Populasi dalam penelitian ini adalahperusahaan Manufaktur yang terdaftar pada Bursa Efek Indonesia (BEI) selama periode 2015 - 2018. Terdapat dua metode pengambilan sampel yaitu probability sampling dan nonprobability sampling. Perusahaan manufaktur yang terdaftar di Bursa Efek Indonesia yang telah memenuhi kriteria sebagai sampel penelitian sebanyak 9 perusahaan selama 4 tahun penelitian, sehingga jumlah data yang digunakan dalam penelitian ini sebanyak 36 data observasi.

\section{Metode Analisis Data}

Dalam penelitian ini, model penelitian dijelaskan dengan bantuan software pengolah data statistik yaitu Eviews 9.0. Model regresi data panel dapat ditulis sebagai berikut:

$\mathrm{KL}_{\mathrm{it}}=\alpha+\beta_{1} \mathrm{ISO}_{\mathrm{it}}+\beta_{2} \mathrm{KAI}_{\mathrm{it}}+\beta_{3} \mathrm{KM}_{\mathrm{it}}+\varepsilon_{\mathrm{it}}$

Dimana:

$$
\begin{aligned}
\mathrm{KL}= & \text { Variabel Kualitas Laba } \\
\alpha \quad= & \text { Konstanta } \\
\beta 1,2,3= & \text { Koefisien Regresi Variabel } \\
& \text { Independen Variabel International } \\
& \text { Standart of Organizagtion } \\
\mathrm{KAI}= & \text { Variabel Kualitas Auditor } \\
& \text { Internal } \\
\mathrm{KM}= & \text { Variabel Kontrak } \\
& \text { Manajemen } \\
\mathrm{i}= & \text { Perusahaan } \mathrm{t} \\
\varepsilon \quad= & \text { Residual/Error }
\end{aligned}
$$




\section{HASIL DAN PEMBAHASAN}

Hasil Uji t menjelaskan signifikansi pengaruh variabel bebas secara parsial terhadap variabel terikat.

Tabel 1. Rangkuman Hasil Analisis Regresi Data Panel

\begin{tabular}{|l|c|c|c|}
\hline \multicolumn{1}{|c|}{ Hipotesis } & $\begin{array}{c}\text { Nilai (t- } \\
\text { statistik) }\end{array}$ & Sign. & Ket \\
\hline Constant & -2.458077 & 0.0196 & - \\
\hline $\begin{array}{l}\text { nternational } \\
\text { Organization for } \\
\text { Standardization (H1) }\end{array}$ & 2.356357 & 0.0247 & Diterima \\
\hline kualitas Auditor (H2) & -2.464956 & 0.0193 & Diterima \\
\hline $\begin{array}{l}\text { Kontrak Manajemen } \\
\text { (H3) }\end{array}$ & -4.101255 & 0.0003 & Diterima \\
\hline $\begin{array}{l}\text { Adjusted R- } \\
\text { squared }\end{array}$ & \multicolumn{3}{|c|}{0.40542} \\
\hline $\begin{array}{l}\text { F } \\
\text { Statistik }\end{array}$ & \multicolumn{3}{|c|}{} \\
\hline
\end{tabular}

Sumber: Data diolah Eviews 9, 2020

Pengaruh International Organization for Standardization terhadap Kualitas Laba

Variabel ISO yang diproksikan dengan jumlah sertifikat ISO pada perusahaan sampel, menunjukkan bahwa investor percaya bahwa dengan menggunakan iso kinerja perushaan akan menjadi baik, hal ini juga kan mempengaruhi terhadap peningkatan kinerja keuangan perusahaan. Perusahaan yang memilik jumlah sertifikat iso yang banyak akan memiliki image yang baik dimata masyarakat, karena masyarakat percaya dengan adanya sertifikat iso maka perusahaan tersebut sudah memiliki standar mutu yang tinggi serta produk yang dihasilkannya juga akan berkualitas. Dengan tingkat kepercayaan masyarakat yang tinggi terhadap perusahaan hal ini juga akan mempengaruhi tingkat penjualan perusahaan dengan demikian laba yang didapat oleh perusahaan akan baik. Semakin baiknya laba yang diperoleh oleh perusahaan maka penilaian investor terhadap perusahaan akan baik serta hal ini akan mempengaruhi investor dalam mengambil keputusan untuk menanamkan modalnya. Dengan demikian laba perusahaan menjadi berkualitas.

\section{Pengaruh Kualitas Auditor Internal terhadap Kualitas Laba}

Variabel Kualitas Auditor Internal yang diproksikan dengan jumlah sertifikat yang diperoleh seorang auditor internal disuatu perusahaan dalam annual report dibagian tata kelola perusahaan, memiliki nilai Prob. 0.0193 < taraf signifikansi (0.05) dan t-statistic (-2464956) > $\mathrm{t}$ Tabel (2.03693), dengan demikian maka $\mathrm{H}_{2}$ ditolak yang artinya kualitas auditor internal berpengaruh negatif terhadap kualitas laba.

Hasil ini berlawanan arah dengan hipotesis yang diajukan bahwa semakin berkualitas auditor internal suatu perusahaan, maka kualitas laba yang diperoleh perusahan akan baik. Perusahaan sampel yang dipilih dalam penelitian ini merupakan perusahaan manufaktur merupakan yang memiliki image yang baik karena perusahaan sampel merupakan perusahaan pemimpin pasar ekonomi dari perusahaan lain yang sejenis. Dengan demikian seharusnya perusahaan tersebut tidak perlu membutuhkan tingkat kualitas auditor internal yang tinggi untuk meningkatkan kepercayaan satkeholder dengan jumlah personel yang banyak. Karena hal tersebut dapat mempengaruhi penilaian stakeholders terhadap perusahaan, dan menduga bahwa di dalamnya terdapat tata kelola perusahaan yang kurang baik. Dugaan tersebut muncul disebabkan oleh upaya perusahaan untuk meningkatkan kualitas auditor internal, maka biaya yang dikeluarkan perusahaan untuk melakukan program pelatihan dan sertifikat profesi auditor internal pun semakin tinggi. Hal ini 
membuat stakeholders memberikan penilaian yang negatif atas informasi laba yang dipublikasikan perusahaan.

\section{Pengaruh Kontrak Manajemen Terhadap Kualitas Laba}

Variabel kontrak manajemen Hasil peneilitan ini menunjukan Variabel kontrak manajemen berpengaruh negatif terhadap kualitas laba. Dengan persaingan ekonomi yang ketat di zaman sekarang ini banyak perusahaan yang melakukan segala cara untuk mendapatkan perjanjian/kontrak kerjasama sebanyak-banyaknya dengan perusahaan lain dan stakeholder agar tujuan perusahaan dalam mendapatkan laba perusahaan bisa terealisasi dengan cepat. Dengan banyaknya kontrak kerjasama fokus perusahaan dalam menjalankan kontrak kerjasama tersebut menjadi berkurang serta agar kontrak kerjasama tetap berjalan tidak sedikit pula perusahaan yang melakukan kecurangan dengan memanipulasi data informasi yang dibutuhkan dalam kontrak kerjasama. Karena hal tersebut dapat mempengaruhi penilaian stakeholder terhadap perusahaan, dan stakeholder menduga bahwa setiap informasi keuangan yang dilaporkan merupakan hasil dari manipulasi data yang dilakukan oleh perushaan. Dengan demikian semakin banyak kontrak perjanjian, maka penilaian stakoldor terhadap perusahan menjadi negative.

Disamping itu, apabila laporan tersebut hanya berisi informasi mengenai perjanjian yang dilakukan perusahaan sampel dengan perusahaan lain tanpa memberikan informasi yang pasti mengenai kinerja keuangan perusahaan ditahun berjalan, maka laporan tersebut tidak cukup memberikan informasi kepada para stakeholders mengenai besarnya laba perusahaan dimasa depan sehingga stakeholder tidak daapat mengestimasi berapa return yang didapat dari perusahaan tersebut.

\section{KESIMPULAN}

Berdasarkan Uraian yang telah dijelaskan, maka dapat menarik kesimpulan, bahwa International Organization for Standardization, Kualitas Auditor Internal dan Kontrak Manajemen berpengaruh positif terhadap Kualitas Laba.

\section{DAFTAR PUSTAKA}

Antariksa, W. F., \& Setiawan, M. (2014). Pengaruh Penerapan Sistem Manajemen Mutu ISO $9001: 2008$ di Perguruan Tinggi terhadap Kinerja Balanced Scorecard (Studi Kasus pada Universitas Brawijaya). Jurnal Aplikasi Manajemen, 12(3), 399406.

Anton, F. (2016). Menuju Teori Stewardship Manajemen. Majalah Ilmiah Informatika Fakultas Ekonomi Universitas AKI Semarang, 1(2), 53-59.

Ariany, V. (2017). Pengaruh Independensi dan Kompetensi Auditor Terhadap Kualitas Audit Internal Pada Bank BUMN di Medan. Riset \& Jurnal Akuntansi, 1(1), 62-69.

Basuki. (2016). Pengaruh Ukuran Perusahaan, Likuiditas dan Invesment Opportunity Set Terhadap Kualitas Laba (Studi Empiris Pada Perusahaan Sub Sektor Food and Beverage yang Terdaftar di Bursa Efek Indonesia Periode 2012-2016) Basuki. IOSR Journal of Economics and Finance, $3(1)$, 56. https://doi.org/https://doi.org/10.3929/ethzb-000238666

Davis, F. D., \& Donaldson. (1997). Copyright (C) 1997. All rights reserved. International Journal of Plant Science, 158, S65-S80.

Dechow. (2010). The Quality of Accruals and Earnings. The Accounting Review, Vol. 77, pp.

$35-59$. https://doi.org/10.2308/accr.2002.77.s-1.35

Dechow, P. M. (2012). Understanding earnings quality: A review of the proxies, their determinants and their consequences. The Accounting Review, 87(6), 1993-2025.

Dichev. (2016). The misrepresentation of earnings. Financial Analysts Journal, 72(1), $22-35$. 
https://doi.org/10.2469/faj.v72.n1.4

Dira, P. K., \& Astika, I. B. P. (2014). Pengaruh struktur modal, likuiditas, pertumbuhan laba, dan ukuran perusahaan pada kualitas laba. E-Jurnal Akuntansi Universitas Udayana, 1(7), 64-78.

Dityatama. (2011). Pengaruh Kualitas Audit Internal Terhadap Efektivitas Sistem Pengendalian Internal Satuan Kerja Perangkat Daerah di Lingkungan Pemerintah Kabupaten Lumajang. 25-33.

Eksandy, A. (2018). Metode Penelitian untuk Akuntansi dan Manajemen. Tangerang: Fakultas Ekonomi dan Bisnis.

Eksandy, A., \& Milasari, E. (2016). Pengaruh Environmental Disclosure, Kualitas Auditor Internal dan Kontrak Manajemen Terhadap Kualitas Laba.

Freeman, R. E. (1984). Strategic management: A stakeholder approach.

Ginting, E. K. P. B. (2014). Pengaruh Kualitas Audit dan Prediktabilitas Laba Akuntansi Terhadap Earnings Response Coefficient (Studi Empiris Perusahaan Manufaktur yang Terdaftar di BEI 2008-2012).

Gramling, A. a, \& Vandervelde, S. D. (2006). Assessing Internal Audit Quality. Internal Auditing, 21(3), 26-30,32-33. Retrieved from

http://search.proquest.com/docview/21439

3978? accountid=13552\%5Cnhttp://findit.li b.rmit.edu.au:9003/sfx_local??genre=articl e\&amp;sid=ProQ:\&amp;atitle=ASSESSIN G INTERNAL AUDIT QUALITY\&amp;title=Internal

Auditing\&amp;issn=0897-

0378\&amp;date=2006-05-01\&amp;vo

Hadi Firmansyah. (2015). Analisis Terhadap Penerapan ISO 9001:2000 dalam Kaitannya dengan Produktivitas dan Kepuasan Pelanggan. 1-27.

Iin Mutmainah. (2015). Pengaruh Struktur Modal, Ukuran Perusahaan, Asimetri Informasi, dan Profitabilitas Terhadap Kualitas Laba. (1), 110-118.

Ilhamsyah, F. (2018). Pengaruh kompetensi, profesionalisme, dan pengalaman kerja auditor terhadap kualitas audit internal pada perbankan artikel.

Jawat, I. W. (2014). Kajian Kontrak/Perjanjian Kerjasama Pengguna Jasa Pengamanan Antara Universitas Warmadewa Sebagai Pengguna Jasa dan PT. Ibu Jero Sebagai Penyedia JAsa (Ditinjau Dari Aspek Manajemen Kontrak). 3, 1-17.
Lesmana, Y., \& Tarigan, J. (2014). Pengaruh sustainability Reporting terhadap Kinerja Keuangan Perusahaan Publik dari sisi Aset Management Ratios. Business Accounting Review, 2(1), 101-110.

Magdalena, M. (2018). Positive Accounting Theory (Pat): Telaah Literatur Dari Berbagai Perspektif. El Muhasaba: Jurnal Akuntansi, $\quad 9(2), \quad 72$. https://doi.org/10.18860/em.v11i2.5271

Maulana, R. (2015). Jurnal Ilmiah Manajemen \& Akuntans. 2, 81-101.

Maya. (2015). Analisis Pengaruh Laverage, Likuiditas, Umur Perusahaan, Ukuran Perusahaan, Siklus Operasi, dan Volatilitas Penjualan Terhadap Kualitas Laba. Ekp, 13(3), 1576-1580.

Mchopa, A. (2015). Integrating Contract Management Practices Into the Procurement: Evidence From Selected Procuring Entities. Journal of Public Procurement, 15(2), 129-149.

Natasya. (2016). Pengaruh Agresivitas Pajak Terhadap Corporate Sosial Responsibility : Untuk Menguji Teori Legitimasi.

pertiwi, putri. (2017). Kualitas laba: Corporate Governance dan Ukuran Perusahaan (Studi pada perusahaan yang terdaftar dalam Indeks Kompas 100 di BEI tahun 20122016). E-Proceeding of Management, 4(3), 2734-2741.

Pitria, E. (2017). Pengaruh Kesempatan Bertumbuh, Leverage dan Profitabilitas Terhadap Kualitas Laba. Universitas Negeri Padang.

Rashidpour, A., \& Mazaheri, M. M. (2016). Evaluation of Agency and Stewardship Approach in Four Units of the Islamic Azad University and Prediction of Their Potential Productivity. Oman Chapter of Arabian Journal of Business and Management Review, 3(5), 34-42. https://doi.org/10.12816/0016451

Rosnidah, I. (2017). Model Pengukuran Kualitas Audit Internal. EKUITAS (Jurnal Ekonomi Dan Keuangan), 17(3), 299. https://doi.org/10.24034/j25485024.y2013. v17.i3.2254

Semuel, H., \& Zulkarnain, J. (2014). Pengaruh Sistem Manajemen Mutu Iso Terhadap Kinerja Karyawan Melalui Budaya Kualitas Perusahaan ( Studi Kasus PT . Otsuka Indonesia Malang ). 162-176.

Subiyanto, N. T. (2012). Independensi Dan Kualitas Auditor Internal Terhadap 
Temuan Audit. Berkala Ilmiah Mahasiswa Akuntansi, 1(2), 83-88.

Sugiyono. (2017). Metode Penelitian Kuantitatif, Kualitatif dan $R \& D$ (Afabeta, Ed.). Bandung.

Sunusi, S. A. (2018). Evaluasi Creative Accounting dalam Pelaporan Keuangan Berdasarkan Perspektif Akuntansi Positif. 1-86. Retrieved from http://repositori.uinalauddin.ac.id/1178/1/rezki.pdf?cv=1

Suwandi, N., \& Daromes, F. E. (2017). Peran Kemampuan Manajerial Sebagai Mekanisme Peningkatan Kualitas Laba Dan Nilai Perusahaan. Jurnal Akuntansi Dan Keuangan Indonesia, 13(2), 174-193. https://doi.org/10.21002/jaki.2016.10

Tumembow, W. yulianti. (2016). Analisis Kontrak Kerja Owner Terhadap Kontraktor ( Studi Kasus: Perumahan Taman Mapanget Raya ). 4(5), 341-348.

Warianto, P. (2014). Pengaruh Ukuran Perusahaan, Struktur Modal, Likuiditas, dan Investment Opportunity Set (IOS) Terhadap Kualitas Laba di Perusahaan Manufaktur Ynag Terdaftar di BEI. Modus, 26(1), 19-32.

Watts, R. L., \& Zimmerman, J. L. (1990). Positive Accounting Theory: A Ten Year Perspective. The Accounting Review, 65(September 1989), 131-156. https://doi.org/10.2307/247880 